out that this provision sets up two classes of exemptions,,$^{70}$ namely: $x$ ) the ownership or acquisition of securities under any indenture, and 2) the ownership or acquisition of any security or securities having a maturity period of a year or more at the time of acquisition by the indenture trustee. As the terms "security" 7 and "indenture" 72 are defined in the act, the first class seems to exempt a creditor relationship arising from a trustee's giving an unsecured short-term loan in return for notes issued under an indenture. Moreover, by the same interpretation, the trustee may give a secured loan knowing the obligor will default within four months, providing the obligor follows the formality of issuing notes for the debt under a mortgage. To prevent circumvention of Section 3II through such interpretations of the above exceptions, it is submitted that such terms as "bona fide," "security," and "indenture," should have been more carefully defined by the act.

\title{
MEASURE OF RECOVERY AGAINST A PROMOTER WHO SELLS PROPERTY TO A CORPORATION IN BREACH OF FIDUCIARY DUTY
}

It is not uncommon for a promoter to profit by selling property to the corporation which he has organized. This profit may be made more or less secure through the adoption of various financing techniques whereby the sale is made at a time when the promoter and his affiliates are the sole shareholders. Inasmuch as all of the existing shareholders in the company may then be said to have consented to the profit with full knowledge, the company is bound and may not later rescind the sale or compel the promoter to disgorge his secret profits. ${ }^{x}$ In the absence of actionable deceit when these shares are later sold to the

${ }^{70}$ The analysis of the Trust Indenture Act made by the SEC in H.R. Rep. Ior6, 76th Cong., Ist Sess. at 49 (I939), does not contradict such an interpretation.

$7 \mathrm{~T}$ The definition of the Securities Act of 1933 is used by the Act, $\S 303(\mathrm{I})$.

Section 2(r) of the Securities Act defines "security" as "any note, stock, treasury stock, bond," etc., 48 Stat. 74 (1933), 15 U.S.C.A. § 77b (Supp. 1939).

72 "The term 'indenture' means any mortgage, deed of trust, trust or other indenture, . . . . under which securities are outstanding or are to be issued, whether or not any property, real or personal, is or is to be, pledged, mortgaged, assigned, or conveyed thereunder." $\$ 303(\mathrm{x})$.

I There is a conflict of authority as to whether an action will lie in favor of the company when there are later subscribers to new shares. One view, following Old Dominion Copper Mining \& Smelting Co. v. Lewisohn, 210 U.S. 206 (Ig08), holds that there is no corporate right of action even though, as part of the promotional scheme, these subscribers are contemplated. There may, however, be individual actions for fraud. Cf. McCandless v. Furlaud, 296 U.S. 140 (1935). The other view, following Old Dominion Copper Mining \& Smelting Co. v. Bigelow, 203 Mass. 159, 89 N.E. 193 (Igog), permits corporate action, holding that the fiduciary duty runs to the corporation as the promoters intended to make it. See CaliforniaCalaveras Mining Co. v. Walls, x70 Cal. 285, 149 Pac. 595 (rgr5); Hays v. The Georgian, 280 Mass. ro, I8r N.E. 765 (r932); In re British Seamless Paper Box Co., I7 Ch. D. 467 (I88r).

See generally, Ballantine, Corporations $\$ 49$ (I927); Stevens, Corporations I68 (I936); I Fletcher, Cyc. Corporations $\S$ I94 (perm. ed. I93I). 
public, ${ }^{2}$ the promoter may retain the profit even though he has avoided making any disclosure to the public of his interest or his profit in the transaction. ${ }^{3}$ Where, however, as part of the promotional scheme, members of the public are permitted to become original purchasers of previously unissued shares, 4 the promoter must generally disclose certain facts pertaining to the transaction in order to make the sale binding on the company and thereby to insure his profit. This disclosure may be made to each subscriber, in the prospectus or otherwise, so that the subscription is made with knowledge and therefore with consent to the terms of the sale, ${ }^{5}$ or it may be made to an independent board of directors when the sale is consummated after the company has been organized. ${ }^{6}$ Should the promoter neglect to make the required discosure in any of the foregoing ways, the company may either rescind the entire transaction 7 or obtain a decree for an accounting and disgorging of secret profits. Two measures of recovery

${ }^{2}$ See Old Dominion Copper Mining \& Smelting Co. v. Lewisohn, 2xo U.S. 206 (Ig08); Allenhurst Park Estates v. Smith, ror N.J. Eq. 58I, I38 Atl. 709 (r927); Tompkins v. Sperry, Jones \& Co., 96 Md. 560, 54 Atl. 254 (I902); Erlanger v. New Sombrero Phosphate Co., 3 App. Cas. I2I8, I264 (H.L. 1878). See also Short v. Stevenson, 63 Pa. 95 (I869).

3 But see McCandless v. Furlaud, 296 U.S. r4o (r935); McCandless v. Furlaud: the End of the Doctrine of Old Dominion Copper Co. v. Lewisohn?, 84 U. of Pa. L. Rev. 409 (I935).

4 See note I supra.

${ }_{5}$ See Simons v. Vulcan Oil Mining Co., 6r Pa. 202 (I869). Such disclosure must be clear, Erlanger v. New Sombrero Phosphate Co., 3 App. Cas. I218 (H.L. I878); Gluckstein v. Barnes, [rgoo] A.C. 240 (H.L.); Arnold v. Searing, 78 N.J. Eq. 146 , 160, 78 Atl. 762 (Igro).

In those jurisdictions which require disclosure to all shareholders contemplated in the promotional scheme, see note I supra, it has been suggested that disclosure made on the books of the company would be adequate as to subsequent shareholders. See Mason v. Carrothers, ro5 Me. 392, 74 Atl. ro3o (Igog). But see Henderson v. Plymouth Oil Co., I6 Del. Ch. 347, r4I Atl. r97 (rg28). See also Alger, Law of Promoters and the Promotion of Corporations $\S 38(1897)$.

${ }^{6}$ Ballantine, Corporations $\S 49$ (1927); I Fletcher, Cyc. Corporations $\S$ I94 (perm. ed. 193I).

Where the members of the public are invited to become holders of new shares in the company, the promoters have a fiduciary duty to provide the company with an independent board of directors, Erlanger v. New Sombrero Phosphate Co., 3 App. Cas. I218 (H.L. I878); Arnold v. Searing, 78 N.J. Eq. $x 46,78$ Atl. 762 (19ro); Plaquemines Tropical Fruit Co. v. Buck, 52 N.J. Eq. 219, 27 Atl. 1094 (1893).

It is said that the promoter on making full disclosure may obtain ratification of the sale by unanimous vote of the stockholders after the company is organized, Old Dominion Copper Mining \& Smelting Co. v. Lewisohn, 210 U.S. 206 (rgo8); cf. Erlanger v. New Sombrero Phosphate Co., 3 App. Cas. I2I8 (H.I. I878).

7 As an alternative to an action for secret profits, the corporation may elect to rescind the transaction whenever there has been inadequate disclosure. In rescission, the burden of showing that the interests of the company received fair treatment is on the promoter, Erlanger v. New Sombrero Phosphate Co., 3 App. Cas. I 218 (H.L. 1878). Where the vendor has paid the promoter a secret commission, the company may have rescissory relief against the vendor. As in the agency cases, this is permitted even though the price paid for the property was a fair one, for it would be impossible to determine how favorable a bargain might have been made had the promoter been loyal to the company. Damages to the amount of the commission would undoubtedly be inadequate, Commonwealth S.S. Co. v. American Shipbuilding Co., 
are used by the courts. Depending on the considerations which this note will discuss, the promoter may be compelled to disgorge either all of his secret profits in the transaction, or only his secret profits in excess of the fair value of the property at the time of resale. ${ }^{8}$

The amount of disclosure required as well as the recovery which the company may have for failure to make that disclosure is generally said to depend on the time when the promoter acquired the interest in the property which he resells to the company. A dictum in the case of Densmore Oil Co. v. Densmore? has been quoted frequently ${ }^{10}$ as setting forth the test. The court said that where the promoter owned the property prior to the assumption of any fiduciary relationship with the nascent corporation, he may resell the property at a fair price, and the transaction will be binding if he reveals his position as seller and thereby indicates that he has an interest in the result of the sale. Furthermore,

I97 Fed. 780 (D.C. Ohio $x_{912)}$; see Limited Investment Ass'n v. Glendale Investment Ass'n, 99 Wis. 54,74 N.W. 633 (1898).

When rescission is decreed, the promoter must account for the purchase price plus interest, and the corporation, in addition to returning the property, must account for any deterioration and depreciation and for the value of its use during the time it held the property. The company may retain the profits made during that time, Erlanger v. New Sombrero Phosphate Co., 3 App. Cas. I2I8 (H.L. I878); Commonwealth S.S. Co. v. American Shipbuilding Co., I97 Fed. 780 (D.C. Ohio I9I2). Partial rescission is not permitted, Alger, op. cit. supra note 5 , at $\S 99$. As to methods for proceeding to rescind, see Ballantine, Corporations $\S 5 I$ (I927).

Rescission, of course, will not be sought where the property is of value to the company, see Henderson v. Plymouth Oil Co., I6 Del. Ch. 347, I4I Atl. I97 (I928), or where the property has been mortgaged so as to make return impossible at that time, In re Leeds \& Hanley Theatres of Varieties, Ltd., [rgo2] 2 Ch. 809.

${ }^{8}$ In most cases there may be little difference due to market fluctuations in value between the cost of the property to the promoter and the fair value at time of resale, inasmuch as the typical promoter seldom retains the property for any length of time. Where, however, the promoter has owned the property for some time, or has made a particularly "sharp" bargain, or the nature of the property is such that its value may fluctuate widely, it is apparent that a considerable differential between actual cost and fair value may exist. See Henderson v. Plymouth Oil Co., I6 Del. Ch. 347, I4I Atl. I97 (I928).

In the absence of a ready market whereby the fair value of the property may be ascertained, value is determined by the court in the light of whatever considerations may be presented. See Old Dominion Copper Mining \& Smelting Co. v. Bigelow, 203 Mass. 159, 89 N.E. I93 (I909); In re Leeds \& Hanley Theatres of Varieties, Ltd., [I902] 2 Ch. 809.

A colorable transfer between vendor and promoter, or between some third party and the promoter for the purpose of creating a fictitious price at which the promoter acquires the property will not be recognized in ascertaining the actual cost of the property, Whaley Bridge Calico Printing Co. v. Green, 5 Q.B.D. 109 (1879); cf. In the Matter of Ypres Cadillac Mines, Itd., 3 S.E.C. $4 \mathrm{I}$ ( 1938$)$.

For the purposes of this note it will be assumed (I) that the court has the means to estimate the fair value of the property, and (2) that a differential exists between actual cost and fair price.

${ }_{9} 64$ Pa. 43 (1870). See Ballantine, Corporations $\$ 94$, n. 5 I (r927); I Machen, Corporations $\S 384$ (Igo8); Liability of Promoters to the Corporation and Its Shareholders for Secret Profits, 26 Col. L. Rev. 447, 450 n. 2 I (I926).

so See I Fletcher, Cyc. Corporations $\S 195$ (perm. ed. I93I). 
it has been suggested that where there has been adequate disclosure, the company may not rescind or bring an action for secret profits even though the price was excessive. ${ }^{\text {II }}$ On the other hand, where the promoter acquired an interest in the property while in a fiduciary relationship with the company, he must resell at actual cost, unless he reveals both his interest in the transaction and the amount of profit he will make. Thus the factor under the Densmore case dictum which determines both the amount of disclosure which the promoter must make and the recovery permitted the corporation for failure to make that disclosure is the point of origin of the fiduciary relationship of the promoter to the company. It is proposed herein to analyze the various applications of the Densmore case dictum, to seek its justification, if any, and to show in what circumstances courts have applied a more realistic approach to the problem in terms of the amount of risk which the promoter has been subjected to in his ownership of the property before resale.

\section{I}

When a promoter owns property, either outright or as the holder of an equitable title under an executory contract of sale, and has acquired his interest before conceiving a plan to form a corporation to which to resell the property, the cases agree that he is under no fiduciary disability at the time of acquisition. ${ }^{\mathrm{Iz}}$ It is said that the promoter may then deal with the subsequently formed corporation much as an ordinary vendor, except that fulfillment of the obligations of the fiduciary relationship which he bears to the company at the time of resale requires that he then reveal his interest in the property. ${ }^{13}$ In disclosing his interest he must usually reveal the estate he holds in the property, ${ }^{14}$ but he need not reveal the amount of his profit. ${ }^{15}$ This disclosure is similar to that

Ir See Spaulding v. North Milwaukee Town-Site Co., xo6 Wis. 48I, 8I N.W. I064 (I900). But see Henderson v. Plymouth Oil Co., I6 Del. Ch. 347, I4I Atl. I97 (1928).

12 Old Dominion Copper Smelting \& Mining Co. v. Bigelow, 203 Mass. I59, 89 N.E. 193 (xgog); Lungren v. Pennell, ro Weekly Notes of Cases 297 (Pa. Sup. Ct. I88r; McElhenny's Appeal, 6I Pa. 188 (I869); Ladywell Mining Co. v. Brookes, 35 Ch. D. 400 (I887); see Burbank v. Dennis, IoI Cal. 90, 35 Pac. 444 (I894) (executory contract).

${ }_{23}$ Milwaukee Cold Storage Co. v. Dexter, 99 Wis. 2I4, 74 N.W. 976 (I898); Robinson v. Draney, 53 Utah 263, r78 Pac. 35 (Igr8); Masberg v. Granville, 20 I Ala. 5 , 75 So. 154 ( 1917 ) (option); Richardson v. Graham, 45 W.Va. 134, 30 S.E. 92 (I898) (option); see Henderson v. Plymouth Oil Co., I6 Del. Ch. 347, I4I Atl. I97 (I928); Yale Gas Stove Co. v. Wilcox, 64 Conn. IOI, 29 Atl. 303 (1894); Rice's Appeal, 79 Pa. I68, 204 (1875). Option cases: South Joplin Land Co. v. Case, I04 Mo. 572, 16 S.W. 390 (I891); Plaquemines Tropical Fruit Co. v. Buck, 52 N.J. Eq. 219, 27 Atl. I094 (I893). Cf. the same rule as to agents, Ely v. Hanford, 65 Ill. 267 ( 1872$)$.

I4 If the promoter holds only an option on the property, it would seem that he must not give the impression of having full ownership. See Yeiser v. United States Board \& Paper Co., I07 Fed. 340 (C.C.A. 6th Igor); Victor Oil Co. v. Drum, I84 Cal. 226, I93 Pac. 243 (r920).

Is See Densmore Oil Co. v. Densmore, 64 Pa. 43 (I87o); Milwaukee Cold Storage Co. v. Dexter, 99 Wis. 214, 74 N.W. 976 (1898); Richlands Oil Co. v. Morriss, ro8 Va. 288, 6r S.E. 762 (Ig08). See also 3 Cook, Corporations $\$ 651$ (8th ed. r923); Ehrich, Promoters $\$ x_{4}$ (I9I6). 
which a corporate director must make on sale to the corporation of property acquired by him before he became a director. ${ }^{16}$ The strict trustee, on the other hand, by reason of a more rigorous application of the loyalty principle, is required to make fuller disclosure. In addition to disclosing his interest, the strict trustee must reveal the amount of benefit he will derive from the transaction and apprise the cestui of his legal rights in the matter. Until the cestui has approved the transaction after such disclosure, he may elect either to rescind without regard to fairness, or he may retain the benefits of the transaction and compel the trustee to disgorge his profits. ${ }^{17}$ The measure of disgorgement in such a case is uncertain and the text writers are not in agreement. ${ }^{x 8}$ In the case of the promoter or director, however, the measure of recovery has been set forth in several cases. If the promoter or director has failed to disclose his interest, the corporation may rescind the transaction or compel the disloyal fiduciary to disgorge all profits above a fair price for the property. ${ }^{19}$ The effect of thus limiting the corporation's recovery to the excess over fair value at the time of resale is to assure the company of a fair bargain while working no extreme hardship on the promoter. Courts explain such a measure of recovery, which in effect merely awards damages for excessive price, ${ }^{20}$ on the theory that the company was in no way harmed since any other profits were made at the expense of the original vendor. ${ }^{2 x}$ As the discussion in part III of this note will show, many courts assert that the policy behind the disclosure requirements is so

${ }^{16}$ Higgins v. Lansingh, 154 Ill. 301,40 N.E. 362 (I895).

${ }^{17} 3$ Bogert, Trusts and Trustees $\$ 489$ (I935).

${ }^{18}$ Professor Bogert, ibid., would permit the cestui to recover the profits of the trustee in any sale of individual property to the trust estate. Professor Scott, 3 Scott, Trusts $\$ 70.12$ (I939), on the other hand, would permit the sale to be made at a fair price, and permit recovery of profits over actual cost only when the trustee purchased for purpose of reselling to the trust estate. See Magruder v. Drury, 235 U.S. 106 (I9 4 ) which is susceptible of either interpretation. Both authors agree that the cestui may rescind until affirmation, even though the property, while worth the price at the time of resale, has since declined in value. See note 56 infra.

I9 Cases cited in notes $I_{2}$ and $x_{3}$ supra. As to the measure of recovery where the promoter has taken his profit in the form of shares in the corporation, see Chandler v. Bacon, 30 Fed. $53^{8}$ (C.C. Mass. I887); Hayward v. Leeson, I76 Mass. 3xo, 57 N.E. 656 (1900); Brewster v. Hatch, I22 N.Y. 349,25 N.E. 505 (I8go). See also Alger, op. cit. supra note $5, \S 92$. There are other miscellaneous remedies: California-Calaveras Mining Co. v. Walls, r7o Cal. 285, I49 Pac. 595 (I9x5) (cancel note not in hands of bona fide purchaser); Midwood Park Co. v. Baker, r28 N.Y. Supp. 954 (S. Ct. I91o); Crowe v. Malba Land Co., 76 Misc. 476, I35 N.Y. Supp. 454 (S. Ct. I9I2) (cancel mortgage held by promoter on the property); Koster v. Pain, 4I App. Div. 443, 58 N.Y. Supp. 865 (S.Ct. I89g) (render unenforceable a contract between promoter and vendor for secret commission (promotion money)).

The corporation may obtain damages for any harm resulting from the failure of the promoter to make adequate disclosure. See Alger, op. cit. supra note 5, c. IV; Cook, Corporation $\$ 65$ I (8th ed. I923).

${ }^{20}$ See opinion of Vaughn, J., in In re Leeds \& Hanley Theatres of Varieties, Ltd., [Igo2] 2 Ch. 809. See also Bentinck v. Fenn, I2 App. Cas. 652 (H.X. 1887); Ladywell Mining Co. v. Brookes, 35 Ch.D. 400 (1887).

${ }^{2 x}$ Henderson v. Plymouth Oil Co., x6 Del. Ch. 347, x4I Atl. I97 (x928). 
strong that some penalty is necessary in order to compel the promoter to disclose his interest. For this reason, these courts, under certain circumstances, decree complete disgorgement of all profits which the promoter may have derived on the transaction ${ }^{22}$ in order to penalize what is termed the "misfeasance" of nondisclosure. ${ }^{23}$

It would seem that except for these last-mentioned cases which prevent the promoter from taking any secret profits, the disabilities of the promoters' fiduciary relationship do not become burdensome under the Densmore dictum unless he acquires the property after becoming a fiduciary. It is important, therefore, to determine when the fiduciary relationship of the promoter begins. The notion that one may be a fiduciary to a beneficiary not yet in existence is at best a fiction, made necessary by the peculiar position which the promoter occupies. ${ }^{24}$ When the corporation is formed it can claim fiduciary responsibility of the promoter from that point prior to its organization at which the court determines the promoter became a fiduciary. It is conceivable that the promoter may become a fiduciary when he formulates his promotional scheme but courts generally do not carry the "relating back" idea that far. ${ }^{25}$ Where one of the first steps in the plan is the purchase of property to be resold when the corporation is in a position to purchase, several courts have declared that the fiduciary relationship begins when the purchase is made. ${ }^{26}$ This view was expressed in

\footnotetext{
22 See Gates v. Megargel, 266 Fed. 8rI (C.C.A. 2d I920); Gluckstein v. Barnes, [1900] A.C. 240 (H.L.).

${ }^{23}$ See Gluckstein v. Barnes, [rgoo] A.C. 240 (H.L.), where the court suggested that interest at the penal rate might be decreed against the promoter on the amount of the judgment and intimated further that the defendant promoter might be unable to claim contribution from his fellow wrongdoers. Generally, liability is joint and several among persons who conspire with the promoter to consummate the transaction whereby a secret profit is obtained, Chandler v. Bacon, 30 Fed. 538 (C.C. Mass. 1887 ); Victor Oil Co. v. Drum, 184 Cal. 226, r93 Pac. 243 (r920). Contra: Loudenslager v. Woodbury Heights Land Co., 58 N.J. Eq. 556, 43 Atl. 67 I (I89g).

${ }_{24}$ "This fiduciary relationship of the promoter is an extension of the doctrine of agency, a sort of agency by anticipation ..... It is a salutary and necessary fiction of equity for the protection of the company," Amold v. Searing, 78 N.J. Eq. 146, 158, 78 Atl. 762 (x9ro).

${ }^{25}$ See Densmore Oil Co. v. Densmore, 64 Pa. 43 (I870); Gates v. Megargel, 266 Fed. 8 II (C.C.A. 2 d r20). See Gluckstein v. Barnes, [rgoo] A.C. 240 (H.L.), where it is said that the fiduciary relationship begins when the promoters select the executives for the proposed company; cf. McCandless v. Furlaud, 296 U.S. I40 (1935).

${ }^{6}$ Mason v. Carrothers, I05 Me. 392, 74 Atl. Io3o (xgog); Arnold v. Searing, 78 N.J. Eq. 146, 78 Atl. 762 (1910); Central Land Co. v. Obenchain, 92 Va. 130, 22 S.E. 876 (1895) (option); Pietsch v. Milbrath, I23 Wis. 647, I02 N.W. 342 (rgo5) (option); Victor Oil Co. v Drum, I84 Cal. 226, I93 Pac. 243 (I920) (option); Yeiser v. United States Board \& Paper Co., I07 Fed. 340 (C.C.A. 6th Igor) (option). The SEC has placed this as the starting point of the fiduciary relationship, In re Oklahoma-Texas Trust, 2 S.E.C. 764 (I937).

When the purchase is part of a preconceived scheme of financing which the promoter carries through to completion with little deviation from the original plan, it is diffcult and seemingly superfluous to single out one particular act with which to begin the fiduciary relationship. The entire scheme should be viewed in its entirety. See Sharp \& Gregory, Labor Law and Social Change 66 ff. (I939). See also McCandless v. Furlaud, 296 U.S. I40 (I935).
} 
the New Jersey case of Bigelowe v. Old Dominion Copper Mining \& Smelting Co. ${ }^{27}$ On the other hand, most courts require that the promoter make some overt act relating to the actual formation of the new corporation in order to be charged as a fiduciary. ${ }^{28}$ Thus, the fiduciary relationship may arise by soliciting subscriptions of the public ${ }^{29}$ or by application for a corporate charter..$^{n}$ This viewpoint was stated in the Massachusetts Old Dominion case, ${ }^{35}$ where the court said that mere intent to form a corporation at the time when the promoter acquired the property was insufficient to charge the promoter as a fiduciary in his purchase.

When the promoter has acquired the property in those jurisdictions where intent at time of purchase is sufficient to charge him as a fiduciary, or when he acquires the property after doing any of the other acts which courts hold serve to charge the promoter as a fiduciary, the subsequently formed corporation has the right to require that resale of such property be made at actual cost. The promoter, by disclosing at the time of resale both his interest in the property and the amount of profit he will make on the transaction, ${ }^{32}$ may retain the profit. Otherwise, the company may rescind or compel him to disgorge all of his secret profits in the transaction, so that the company will acquire the property at the price the promoter paid the actual vendor. ${ }^{33}$ This remedy is a threaten-

${ }_{27} 74$ N.J. Eq. 457, 7I Atl. I53 (Igo8). The director who purchases intending to resell to the company is generally required to disclose his interest and his profit to an independent board of directors. Should he fail to do so, he may be compelled to disgorge all of his profits above actual cost. See Higgins v. Lansingh, I54 Ill. 3 or, 4 o N.E. 362 (I895); Bliss Petroleum Co. v. McNally, 254 Mich. 569,237 N.W. 53 (I93I). The promoter may be analogized only if intent is the controlling factor. On the other hand, these director cases have been interpreted as ones in which the director has diverted corporate opportunities. See Liability of Directors for Taking Corporate Opportunities, Using Corporate Facilities, or Engaging in a Competing Business, 39 Col. L. Rev. 2I9 (r939). Such an analysis would not apply to the promoter unless the company is in existence at the time of his acquisition.

${ }^{28}$ Ladywell Mining Co. v. Brookes, 35 Ch.D. 400 (1887); Henderson v. Plymouth Oil Co., I6 Del. Ch. 347, I4x Atl. I97 (I928); Erlanger v. New Sombrero Phosphate Co., 3 App. Cas. I218, I235 (H.L. I878); Allenhurst Park Estates v. Smith, Ior N.J. Eq. 58I, I38 Atl. 709 (1927).

${ }^{29}$ Short v. Stevenson, 63 Pa. 95 (I869); Ladywell Mining Co. v. Brookes, 35 Ch.D. 400 (1887).

${ }^{30}$ South Joplin Land Co. v. Case, ro4 Mo. 572, I6 S.W. 390 (I89r).

3x Old Dominion Copper Mining \& Smelting Co. v. Bigelow, 203 Mass. I59, 89 N.E. I93 (Ig०9).

${ }^{32}$ See Loudenslager v. Woodbury Heights Land Co., 58 N.J. Eq. 556, 43 Atl. 67I (1899); Brewster v. Hatch, I 22 N.Y. 349, 25 N.E. $5 \circ 5$ (I89o); Bigelow v. Old Dominion Copper Mining \& Smelting Co., 74 N.J. Eq. 457, 7 I Atl. I53 (rg08); Gluckstein v. Barnes, [I900] A.C. 240 (H.L.); Yeiser v. United States Board \& Paper Co., Io7 Fed. 340 (C.C.A. 6th rgor); Gates v. Megargel, 266 Fed. 8II (C.C.A. 2d I920). See note I5 supra.

33 Mason v. Carrothers, I05 Me. 392, 74 Atl. ro3० (rgog); Chandler v. Bacon, 30 Fed. 538 (C.C. Mass. I887); Brewster v. Hatch, r22 N.Y. 349, 25 N.E. 505 (1890). See Bigelow v. Old Dominion Copper Mining \& Smelting Co., 74 N.J. Eq. 457, 7I Atl. I53 (rgo8); Victor Oil Co. v. Drum, I84 Cal. 226, I93 Pac. 243 (I920); Yeiser v. United States Board \& Paper Co., I07 Fed. 340 (C.C.A. 6th Igor); Tilden v. Barber, 268 Fed. 587 (D.C.N.J. r920); cf. Arnold v. Searing, 78 N.J. Eq. 146, 78 Atl. 762 (19ro). 
ing one, for the corporation now has the power to deprive the promoter of all benefits of the transaction when he has failed to make an adequate disclosure.

The Densmore case dictum which bases the extent of the promoter's fiduciary obligations on the time order in which he has arranged his transactions, is thus an instance of the tendency of some courts which has been observed above to permit the form in which the transaction is carried through to be decisive in promoter cases. ${ }^{34}$ Furthermore, it has been seen that by using the time at which the fiduciary relationship of the promoter begins as the factor determining the amount of disclosure required and the amount of disgorgement which the corporation may compel when there has been a failure to make that disclosure, the courts are not adopting a convenient test, for the determination of when the fiduciary relationship starts is in itself a question of some nicety. As an analysis of the possible policy arguments for requiring disclosure will show, there does not seem to be any cogent reason for using a temporal basis on which to distinguish the amount of disclosure which should be required of the promoter. The existence of two different rules for measuring recovery, however, may be accounted for and explained on the basis of the promoter's having assumed certain hazards of ownership during the interim between purchase and resale of the property.

\section{II}

The reason most frequently advanced for placing the promoter who sells property to his corporation under any obligation greater than that of other vendors is the reliance which the public places on him in response to his solicitation to join him in the new enterprise. ${ }^{35}$ This reliance, together with the almost complete control which the promoter generally has over the early organization and functioning of the company have made the imposition of a duty of good faith and fair dealing desirable and necessary in order to protect the funds of the investor and to discourage the promoter from taking unfair advantage of his strategic position. ${ }^{36}$ Moreover, it is economically desirable that the investing public be adequately informed of the constituent values of the new company, in order that the market will more accurately reflect the value of the securities of the new company. ${ }^{37}$ These policy arguments, however, do not suggest any strong reason for differentiating the disclosure required of the promoter on the basis of when he acquired an interest in the property which he resells to the

34 See text accompanying note $I$ supra.

35 This reasoning, however, has not been carried to the extent of protecting shareholders who purchase shares from the promoter or from the corporation after the promoter has taken care to vote these shares in consent of the transaction. See Hays v. The Georgian, 280 Mass. Io, I8I N.E. 765 (1932).

${ }^{36}$ Arnold v. Searing, 78 N.J. Eq. I46, 78 Atl. 762 (I9ro); Rice's Appeal, 79 Pa. 168, 204 (1875); Tegarden v. Big Star Zinc Co., 7 I Ark. 277, 72 S.W. 989 (1903); South Joplin Land Co. v. Case, I04 Mo. 572, I6 S.W. 390 (r89I).

37 See Berle, Cases on Corporation Finance 6I4 (I930); The Securities Act of 1933, The Modern Corporation and the Theory of Free Enterprise, 6 Univ. Chi. L. Rev. 399 (1939). 
company. Rather do these arguments indicate that the duty of disclosure should be comprehensive enough to give the subscribers or the independent board of directors sufficient information to form an adequate picture of the transaction.

The property involved in promotion cases seldom has a market by which its value can be ascertained with any degree of accuracy. In the usual case, however, the promoter does not retain the property for any length of time. A convenient if not necessary item in determining the value of the property, therefore, may be the price which the promoter himself paid for the property a short time before in an arm's length transaction with the vendor..$^{38}$ It would seem, however, that this would be a significant item only when it is necessary to provide the investor or the corporation with data sufficient for it to pass considered judgment on the sale. ${ }^{39}$ The adequacy of disclosure in any given transaction should therefore not be dependent on when the property was acquired by the promoter, but rather on whether the data which has been revealed presents a complete and fair description of the deal and its terms. This test of fairness has been adopted by several courts ${ }^{40}$ as well as in the disclosure requirements of the Securities and Exchange Commission. The commission does not differentiate on the basis of whether the property was acquired before or after becoming a fiduciary, but requires that along with disclosing the interest which the promoter may at any time have had in the property, there must be disclosure of the cost to him of that interest. $4 x$

The more rigorous the remedy which the corporation may have for failure of the promoter to make adequate disclosure, the greater deterrence there is to secrecy, with the result that there is more chance of bringing about the disclosure desired. The more severe the remedy, the less worthwhile it becomes for the promoter to risk his profits by making a sale with inadequate disclosure. It would seem, therefore, that a prophylactic rule which deprives the promoter of all secret profits when there has not been a full and fair disclosure may be desirable.

${ }^{38}$ See note 8 supra.

${ }^{39}$ Thus, where the promoter has owned the property for several years before undertaking the organization of the corporation, the price he paid for the property may no longer be significant as indicating present value and the disclosure of his cost may be unnecessary. Cf. the disclosure requirements of the SEC on Form A-O-I; see note $4 \mathrm{r}$ infra.

${ }^{40}$ Gates v. Megargel, 266 Fed. 8II (C.C.A. 2d 1920); see Richlands Oil Co. v. Morriss, I08 Va. 288, 6r S.E. 762 (I908); Jessel, M.R., in New Sombrero Phosphate Co. v. Erlanger, 5 Ch.D. 73, II2 (1877), aff'd 3 App. Cas. I2I8 (H.L. I878).

${ }_{41}$ Registration Form A-I does not specifically require the registrant to set forth the cost to the promoter of the property; it merely requires full particulars "of the nature and extent of the interest." See In the Matter of Continental Distillers \& Importers Corp., I S.E.C. 54 (I935) where there is an indication that cost to the promoter is significant in determining the extent of the promoter's interest. See also In the Matter of Old Monroe Brewing Ass'n, I S.E.C. $59^{2}$ (1936). Registration Form A-O-I requires the registrant to set forth the cost of the property to the promoter if acquired within ten years of resale to the company, Item $x_{2}(c)$. See also Item 8. 
Beyond this, however, the policy reasons for requiring disclosure may be separated from the policies which conceivably govern the amount of relief which the corporation should be allowed on breach of the fiduciary duty to disclose. It is arguable that the promoter should be permitted to retain some benefit from the transaction as compensation for his services in the promotion, including his services in making the property available to the corporation. Although the promoter renders services of management and performs other valuable functions in getting the corporation under way, the allowance of promotion fees is solely within the discretion of the company when it is fully organized. The promoter, unlike the agent, is unable to claim compensation for his services..$^{42}$ Perhaps this is due to the fact that promotional activity since its inception has been marked by large profit taking, which has been considered a good substitute for fees. ${ }^{43}$ Nevertheless, it would seem that limitations on the profit to be obtained by promotional activity must certainly tend to discourage such activity, and the extent to which a free enterprise can afford such discouragment is itself limited. The function of discovering business opportunities and of aggregating capital for their exploitation must be performed, and if the law eliminates all financial incentive for its performance, a system of private enterprise would seem unworkable. All this, however, simply argues that the promoter should be entitled to compensation for his services. By disclosing the fees he desires to receive to each subscriber by means of the prospectus or otherwise, the promoter may insure remuneration. ${ }^{44}$ Conceivably, the promoter, like the agent, should also be given an action for quantum meruit. The main objection to this is the difficulty which attends any attempt to appraise the problematical value of the promoter's services. In this respect, the practice of paying the promoter in shares, whose value will depend on the success of the venture, has merit. It is the difficulty of placing value on services which probably accounts in large part for the fact that secret profit taking has not been prohibited entirely. The fact, however, that the right of an agent to quantum meruit is not limited to routine functions, the value of which may be readily ascertained, indicates that the problem is not insoluble. 45

Compensation, therefore, as an incentive to promotional activity and in

${ }^{42}$ I Thompson, Corporations § I03 (I927); see Hinkley v. Sac Oil \& Pipe Line Co., I32 Iowa 396 , I07 N.W. 629 (x906).

${ }_{43}$ See Robinson v. Draney, 53 Utah 263 , I78 Pac. 35 (I918) where the court refused recovery of a small secret profit on the ground that the profit was no more than the services of promotion were worth. See also Allenhurst Park Estates v. Smith, ror N.J. Eq. 58r, 609, I38 Atl. 709 (1927). In Mason v. Carrothers, ro5 Me. 392, 74 Atl. ro3o (I909) the court permitted the promoter to set off the value of his services against the decree granting the corporation recovery for secret profits.

${ }_{44}$ See note 4 supra. Central Land Co. v. Obenchain, 92 Va. I30, 22 S.E. 876 (1895). It is yet to be proved whether such full disclosure as required by the SEC, see note 4I supra, will result in so reducing the compensation which the promoter will receive as to discourage promotional activity.

45 See I Mechem, Agency $\$ \S$ I526-9 (2d ed. 19I4). 
return for services rendered in the organization and early management of the company may be made in the form of promotion fees. While it is true that promotion fees and any profit from resale of property which the court will permit the promoter to retain are alike in that both may be had with the knowing approval of the company, the right of a promoter to profits arises from a source different from that of fees. $4^{6}$ Profits which derive from a change in the market value of the property between the time of acquisition by the promoter and its resale to the corporation are speculative in nature. 47 Unless the court wishes to decree complete disgorgement of profits above actual cost as a sanction to induce disclosure, the determination of whether the promoter is entitled to retain any benefit from the transaction should depend on the amount of economic risk which he has borne as a consequence of the ownership of property transferred to the corporation. While to some extent this notion that the promoter has borne certain risks in the ownership of the property is present in the Densmore case dictum, an analysis of the cases wholly in terms of risk may lead to a clarification of the reasons for the use of two different measures of liability in the secret profit cases and indicate more explicitly the various situations in which each measure is applied.

\section{III}

Assuming that the remedy of disgorgement is not to be used as a penalty for non-disclosure, it would seem that if the promoter is to retain the profit arising from an increase in the value of the property which he resells to the company, he should be permitted to do so only when he has assumed the risk of a decline in value during the period of his ownership. The amount of risk which he may be subjected to is a variant of several factors. These may be separated into the nature of his interest in the property, the amount of his investment, and the length of time he has held this interest before resale.

It has been indicated that under the Densmore case dictum, the promoter may resell at a fair value when he owned the property before becoming a fiduciary of the company, but he may not make any secret profit on property acquired after becoming a fiduciary. Once acts of promotion have started and the organization of the company is under way, the likelihood that the promoter will have a purchaser is increased. Acquiring an interest in property becomes

${ }^{46}$ The difficulty of placing value on the property, as distinguished from the value of the promoter's services, has in the past made it difficult to impose any liability for stock watering when the promoter has been paid in shares of stock. See 2 Bonbright, Valuation of Property 797 (1937). Registration forms of the SEC require that payments to the promoter as fees be kept separate from payments given in exchange for property, Form A-I, Items 40, 4r. Form A-O-r, Items 8, 9. See In the Matter of Unity Gold Corp., I S.E.C. 25 (1934); In the Matter of Paper Sales Company of Detroit, 2 S.E.C. 748 (1937).

47 Profits, to a certain extent, are the return for economic risks assumed without the guaranty of a fixed return. See Knight, Risk, Uncertainty, and Profit c. II (r933). 
less hazardous as the scheme of promotion advances towards completion. This is a gradual progression, however, and the risk of ownership to the promoter does not, as the Densmore dictum may imply, depend wholly on whether or not he is a fiduciary to the company. The promoter who has an absolute interest in the property may bear the risk of fluctuation in value up to the time of resale, notwithstanding the fact that he may be a fiduciary to the company. On the other hand, the promoter who has only an option on the property may bear no risk even though he obtained the option long before he became a fiduciary. Furthermore, it should be noted that the emphasis in the Densmore dictum is on the order of transactions rather than on the length of time of ownership.

The length of time which the promoter holds his interest, therefore, should be a consideration, but not a conclusive one, in determining whether he is entitled to resell at actual cost or fair value. Thus, when there is an absolute interest, the fact that it is held for a brief interval before resale should not limit the application of the fair value standard. Unless the property is of a nature which is subject to sharp fluctuations in value, the fair value will usually coincide with actual cost. If its value does fluctuate sharply, then the promoter has borne the risk of rapid decline in value and conversely should get the benefits of a rise. Where standards other than cost to the promoter are available to show value, and it is found that the value has not changed during the period of ownership, but rather a lower cost to the promoter was due to his acumen and ability to secure a "sharp" bargain, the value of the bargain should be his, in the absence of any ability of the company to claim that the purchase was made for its benefit. $4^{8}$

The nature of the promoter's interest in the property is important in determining whether his ownership has subjected him to the hazards of fluctuation in value. Absolute interest as well as an interest as vendee under an executory contract are alike in causing the legal or equitable owner to bear the risk of a decline in value. In the usual case, however, the promoter does not own the property prior to undertaking the promotion of a company, but has merely an option or conditional contract giving him the right to purchase at a future date. Many courts deal with such conditional interests in the same manner as with absolute interests..$^{9}$ On the other hand, there are courts which argue that since the promoter, by the option, has bound himself to nothing, he is not en-

${ }^{8}$ This may be done ( $I$ ) when the promoter represents to the subscribers that the purchase was made for the benefit of the corporation, Plaquemines Tropical Fruit Co. v. Buck, 52 N.J. Eq. 219, 29 Atl. rog4 (I893), (2) under a resulting trust where corporate funds are used by the promoter in his purchase, Wills v. Mehalem Coal Co., 52 Ore. 70, 96 Pac. 528 (rgo8), (3) the purchase is made ostensibly in the name of the corporation, Ballantine, op. cit. supra note $I$.

19 Gover's Case, I Ch.D. 182 (1875); South Joplin Land Co. v. Case, I04 Mo. 572, I6 S.W. $39 \circ$ (I89I); Pietsch v. Milbrath, I23 Wis. 647, I02 N.W. 342 (I905); see Mississippi Lumber Co. v. Joice, I76 Ill. App. IIo (Igr2). 
titled to benefit when the corporation purchases the property.50 Having determined to take up the option only if the corporation proves a purchaser, the promoter has risked nothing in the enterprise. It is true that the promoter, in his option, has a valuable and saleable interest. Should he act fairly and disclose his interest and its value to the company, there is no objection to his profiting. The policy behind requiring disclosure, however, combined with the fact that he has incurred no risk should be sufficient to deprive him of any secret profit. Promotion fees afford adequate compensation for his services in making the property available to the corporation.

The promoter who has an option may deal with his interest in any of three ways. First, he may, as indicated above, sell his interest in the option to the company, and profit thereby. ${ }^{5 x}$ Second, he may secure the option before the organization of the company has started, and later, confident of its willingness and ability to purchase the property from him, take up the option, either by purchasing it or changing it into an executory contract..$^{22}$ In such a case, he is then in the position of the absolute owner with attendant risks, measured by changes in the value of the property from the time of his acquisition, but tempered by the fact that his ownership was brief and commenced when there was likelihood of an available and willing purchaser. The change in value that accrues between the time the promoter acquired the option and his use of it should belong to him, inasmuch as he secured his interest by reason of foresight and had the power to take advantage of that differential by reselling to anyone. ${ }^{53}$ In the third possible situation, the promoter takes up the option only after he has contracted with the company for its resale. 54 In such a case, of course, the promoter has borne no risk and should receive no profits. While the promoter may be subjected to rescission by the company and take a loss there-

5o Burbank v. Dennis, Ior Cal. 90, 35 Pac. 444 (I894); Exter v. Sawyer, I46 Mo. 302, 47 S.W. 95 I (I898); Midwood Park Co. v. Baker, I28 N.Y. Supp. 954 (Sup. Ct. I910); Richlands Oil Co. v. Morriss, 108 Va. 288, 6 r S.E. 762 (rgo8); dissent of Mellish, L.J., in Gover's Case, I Ch.D. I82, I89 (I875); Victor Oil Co. v. Drum, I84 Cal. 226, I93 Pac. 243 (I920); see Brewster v. Hatch, I22 N.Y. 349, 25 N.E. 505 (I89o); Hebgen v. Koeffler, 97 Wis. 313, 72 N.W. 745 (I897); cf. Watson v. Bayliss, 62 Wash. 329, Ir3 Pac. 770 (rgII) (agency).

5x Garretson v. Pacific Crude Oil Co., 146 Cal. I84, 79 Pac. 838 (I905); Central Land Co. v. Obenchain, 92 Va. 130, 22 S.E. 876 (1895); Masberg v. Granville, 201 Ala. 5, 75 So. I54 (Igr7); see Mississippi Lumber Co. v. Joice, I 6 Ill. App. Iro ( $\mathrm{x}_{912}$ ); Simons v. Vulcan Oil \& Mining Co., 6I Pa. 202 (I869); Richardson v. Graham, 45 W.Va. x34, 30 S.E. 92 (I898); cf. Hayward v. Leeson, I76 Mass. 310, 57 N.E. 656 (Igoo).

52 But see Crowe v. Malba Land Co., 76 Misc. 476, 335 N.Y. Supp. 454 (S.Ct. I9r2); Brewster v. Hatch, I22 N.Y. 349, 25 N.E. $5 \circ 5$ (I89o).

${ }_{53}$ See Plaquemines Tropical Fruit Co. v. Buck, 52 N.J. Eq. 219, 27 Atl. I094 (1893). See also note 48 supra.

s Burbank v. Dennis, Ior Cal. 90, 35 Pac. 444 (I894); Midwood Park v. Baker, I28 N.Y. Supp. 954 (Sup. Ct. Igro); Yeiser v. United States Board \& Paper Co., ro7 Fed. 340 (C.C.A. 6th Igor); Wills v. Mehalam Coal Co., 52 Ore. 70, 96 Pac. 528 (Igo8). See South Joplin Land Co. v. Case, I04 Mo. 572, I6 S.W. 390 (I89I). 
on, ${ }^{55}$ this risk arises from his failure to make a fair disclosure and not from his brief ownership of the property. The risk of the promoter is further mitigated, moreover, when he uses funds of the corporation to secure his purchase.

Frequently in promotion cases the promoter uses no funds of his own to obtain the property; rather, transactions are arranged so that income from the corporate subscribers is used to pay the vendor, the promoter taking the opportunity as intermediary to divert part of the price to his secret profit..$^{6}$ This situation may arise under an executory contract as well as in the option case. In the New Jersey Old Dominion case $\mathrm{S}^{57}$ the court suggested that whether the company is entitled to claim the benefit of the bargain made by the promoter "may depend upon whether the promoter buys the property with his own money or with money that is in effect subscribed for the share capital." Several courts in cases where the promoter has been permitted to retain his profit have, in the course of their decision, emphasized that in purchasing the property the promoter used his own resources. ${ }^{8}$ No case has been found, however, which required the promoter to disgorge all profits over actual cost simply because he used corporate funds in making his own purchase.

The question of whose funds are used becomes significant in some cases when the promoter has made representations that he is entering the company on an equal basis with the other subscribers or that "all will share equally in the benefits." Some courts treat this situation as a type of joint undertaking or joint enterprise and create a fiduciary duty running from the promoter to the subscribers to carry through the transaction without secret profit.59 In addition, some courts give the company the right to compel the promoter to turn the property over to it on a purchase money resulting trust theory ${ }^{60}$ The use of

ss Rescission may be had even though the property has declined in value since the sale was made. In such a case the loss will fall on the promoter, even though it does not flow from the breach of his fiduciary duties, see Commonwealth S.S. Co. v. American Shipbuilding Co., I97 Fed. 797 (D.C. Ohio I912); Erlanger v. New Sombrero Phosphate Co., 3 App. Cas. 1218 (H.L. I878).

${ }^{56}$ One of these transactions is detailed in McCandless v. Furlaud, 296 U.S. I40 (I935). See also Yeiser v. United States Board \& Paper Co., ro7 Fed. 340 (C.C.A. 6th Igor); Wills v. Mehalem Coal Co., 52 Ore. 70, 96 Pac. 528 (1908).

57 See also Arnold v. Searing, 78 N.J. Eq. 146, 159, 78 Atl. 762 (r9ro). But see Henderson v. Plymouth Oil Co., I6 Del. Ch. 347, r4x Atl. I97 (I928).

${ }^{58}$ See Ladywell Mining Co. v. Brookes, 35 Ch. D. 400,407 (1887); Craig v. Phillips, 3 Ch. D. 722, 735 (I876). See also Brewster v. Hatch, I22 N.Y. 349, 25 N.E. 505 (I890).

59 Maxwell v. McWilliams, 145 Ill. App. 555 (rgo8); see Getty v. Devlin, 54 N.Y. 403 (I873); Brewster v. Hatch, I22 N.Y. 349, 24 N.E. 505 (I89o); Moore v. Warrior Coal \& Land Co., 178 Ala. 234, 59 So. 2x9 (I9I2); cf. Humbird v. Davis, 2ro Pa. 3 II, 59 Atl. I082 (I904); Yeaney v. Keck, I83 Pa. 532, 38 Atl. I04I (I898).

${ }^{60}$ Parker v. Boyle, 178 Ind. 560, 99 N.E. 986 (I9r2); Pittsburg Mining Co. v. Spooner, 74 Wis. 307, 42 N.W. 259 (1889); Mississippi Lumber Co. v. Joice, I76 Ill. App. IIo (Igr2); Wills v. Mehalem Coal Co., 52 Ore. 70, 96 Pac. 528 (Ig08). See Evan's Appeal, 8x Pa. 278 (I876) where laches intervened to prevent resulting trust. Where corporate funds constitute a part of the consideration, a trust would arise pro tanto only. See Allenhurst Park Estates v. Smith, zor N.J. Eq. 58I, 6I r, I38 Atl. 709 (r927). See also Rest., Restitution $§$ r94 (1937). 
these theories in order to compel disgorgement, however, is unnecessary where representations of a limited profit exist. In any case a promoter otherwise entitled to a profit may, by his acts and declarations when he becomes a fiduciary, lose the benefits of ownership and be required to sell to the company at cost. This may occur, for example, when he represents to subscribers that the company will acquire the property at actual cost. ${ }^{6 x}$ Such voluntary waiver of any right to a profit is enforced because of the reliance which such declarations engender. Similarly, when the promoter represents a specific amount as his sole profit or commission, he will be held strictly to that amount. ${ }^{62}$

From the foregoing, it will be seen that courts to a limited extent are influenced by the application of a test of whether the promoter has borne the risks of ownership and especially the hazard of changes in value of property which he sells to the company he has formed, in determining whether he should be compelled to disgorge his profits when the resale was made without adequate disclosure. The traditional treatment of this question by the courts in terms of whether the property was acquired by the promoter before or after he became a fiduciary of the company has been found inadequate. Certainly, there would seem to be no reason for so distinguishing the amount of disclosure which the promoter must make on resale. If the policy for requiring disclosure is to be realized, the remedy which the company is given should be sufficiently rigorous to compel the desired disclosure. A prophylactic rule would require the promoter to disgorge all secret benefits arising from the transaction. Should courts hesitate to apply so complete a sanction, then the right of the promoter to retain any secret profit from property sold to the corporation should depend upon whether he has borne sufficient risks in the ownership of the property to entitle him to compensation therefor, such compensation to be made in terms of any increase in its value during his ownership. Even if he has borne the risk of changes in the value of the property, however, he may be compelled to forego any profit upon its resale to the corporation if he has made representations indicating that he will not profit from the transaction.

6x Burbank v. Dennis, ror Cal. 90, 35 Pac. 444 (1894); Pittsburg Mining Co. v. Spooner, 74 Wis. 307, 42 N.W. 259 (1889); California-Calaveras Mining Co. v. Walls, r7o Cal. 285, I49 Pac. 595 (I9I5); Hebgen v. Koeffler, 97 Wis. 3I3, 72 N.W. 745 (I897); Yale Gas Stove Co. v. Wilcox, 64 Conn. Ior, 29 Atl. 303 (r894).

62 Davis v. Las Ovas Co., 227 U.S. 80 (I9r2); Tegarden v. Big Star Zinc Co., 7 I Ark. 277, 72 S.W. 989 ( 1903$)$. Where there was a statement in the prospectus that the company will acquire the property at actual cost, the promoter is held to that representation, Central Land Co. v. Obenchain, 92 Va. I30, 22 S.E. 876 (1895). But see Milwaukee Cold Storage Co. v. Dexter, 99 Wis. 214, 74 N.W. 976 ( 1898 ). When the promoter does not disclose his interest but represents his vendor as the seller to the company, he is held to that representation, Plaquemines Tropical Fruit Co. v. Buck, 52 N.J. Eq. 219, 27 Atl. 1094 (1893). 